4-ORIGINAL ARTICLES

\title{
Serological under expression of microRNA-21, microRNA-34a and microRNA-126 in colorectal cancer $^{1}$
}

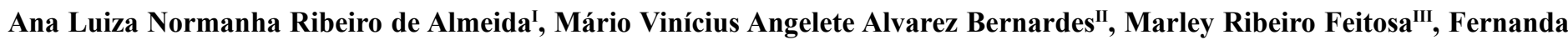 \\ Maris Peria $^{I V}$, Daniela Pretti da Cunha Tirapelliv, José Joaquim Ribeiro da Rocha ${ }^{\mathrm{VI}}$, Omar Feres ${ }^{\mathrm{VII}}$
}

DOI: http://dx.doi.org/10.1590/S0102-86502016001300004

IMD, PhD, Division of Coloproctology, Department of Surgery and Anatomy, Ribeirão Preto Medical School, University of São Paulo. Conception and design of the study, acquisition of data, manuscript writing, manuscript review.

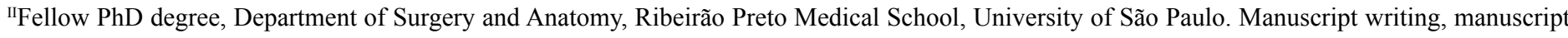
review.

IIIMD, Division of Coloproctology, Department of Surgery and Anatomy, Ribeirão Preto Medical School, University of São Paulo. Manuscript writing, manuscript review.

Iv PhD, Head of Division of Clinical Oncology, Ribeirão Preto Medical School, University of São Paulo. Manuscript review.

${ }^{\mathrm{V}} \mathrm{PhD}$, Department of Surgery and Anatomy, Ribeirão Preto Medical School, University of São Paulo. Manuscript review.

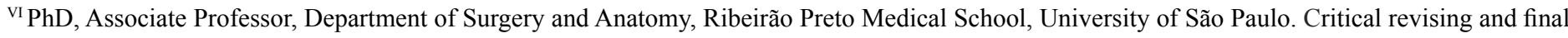
approval of the version to be published.

VII PhD, Associate Professor, Department of Surgery and Anatomy, Ribeirão Preto Medical School, University of São Paulo. Critical revising and final approval of the version to be published.

\begin{abstract}
PURPOSE: This paper describes the ability of miRNA value predict oncological outcomes in CRC patients and correlates to clinical and pathologic variables.

METHODS: We prospectively analyzed the serological expression of microRNA-21, microRNA-34a, and microRNA-126 in 37 stage II - IV CRC patients and correlate to seven fit counterparts. Serological microRNAs were extracted using the miRNeasy Mini Kit $\mathbb{R}$ (Qiagen, Hilden, Germany). Quantification of microRNAs was performed using TaqMan Master Mix® reagent (Applied Biosystems, USA).

RESULTS: We obtained serological underexpression microRNA-21, microRNA-34a, and microRNA-126 in CRC group. However, miRNAs serological values do not impact prognosis. Furthermore, miRNAs was not influenced by CEA values, TNM staging, and histological subtype.
\end{abstract}

CONCLUSION: Despite lower expression of miR-21, miR-34a and miR-126 in the CRC group, no association with poor prognosis was found.

Key words: Colonic Neoplasms. Colon. Drug Therapy. MicroRNAs. Serum. 


\section{Introduction}

Colorectal cancer $(\mathrm{CRC})$ is the third most common malignancy in Western countries and, despite advances in diagnosis and treatment, it is the second leading cause of cancer death in the United States ${ }^{1}$. In Brazil, CRC is the fourth most common malignancy, and more than 32000 new cases of the disease were estimated for $201^{2}$.

If detected at an early stage, the prognosis of the disease is considered good, and 5-year survival rate may reach $65 \%$. However, even with optimal treatment, $40-50 \%$ of patients may experience recurrence of the disease during follow-up ${ }^{3}$.

Classic predictors of tumor behavior include tumor grade, TNM stage, positive surgical margins, histological subtype, obstructive or perforated tumors, lymphovascular and perineural invasion, locally advanced disease and less than 12 lymph nodes recovered to analysis ${ }^{4-6}$.

Micro RNAs (miRNA) are single-stranded molecules of 20-24 nucleotides in length, considered as regulators of gene expression at a post-transcriptional level ${ }^{7,8}$. They are involved in several biological processes and have recently been associated with carcinogenesis, therapeutic response, and prognosis $^{9}$ (Figure 1). Micro RNAs can be divided in oncogenic miRNA (Oncomirs), those related to tumor development, and tumor suppressor miRNA, that usually prevent the development of malignancies by inhibition of proto-oncogenes ${ }^{10}$.

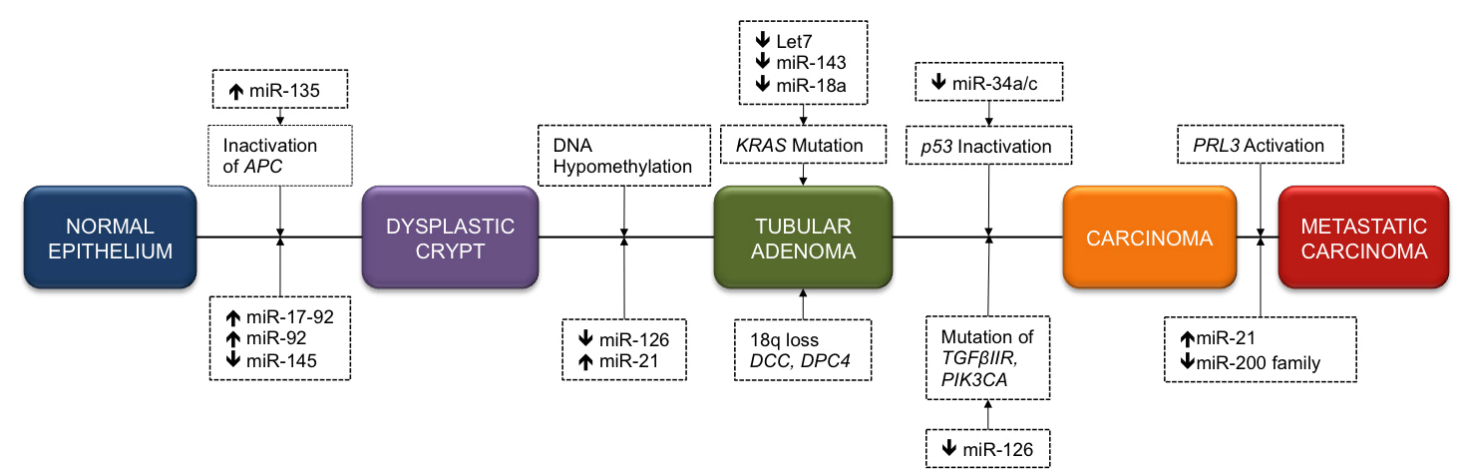

FIGURE 1 - Chromosomal instability pathway of the adenoma to carcinoma sequence. Involved up- ( $\uparrow)$ and down- $(\downarrow)$ regulated miRNAs are indicated. Adapted from Hrašovec and Glavač ${ }^{11}$.

The dosage of serum levels of some miRNAs may prove to be a valuable tool to diagnose CRC or to detect recurrence ${ }^{12}$. The primary objective of this study analyzes the serum levels of miR-21, miR-34a and miR-126 in patients with CRC and make a correlation with prognosis variables.

\section{Methods}

After approval by the Research Ethics Committee, a prospective study was performed with 37 consecutive CRC patients undergoing curative surgery at Clinics Hospital-University of São Paulo (Ribeirão Preto, SP, Brazil), in April 2008-February 2009.

All patients provided informed written consent for enrollment in the study. Exclusion criteria included genetic CRC related to genetic syndromes, non-curative surgery, previous chemotherapy and radiotherapy and refusal to provide written informed consent.

Variables collected from medical records included gender, age, tumor site, histologic subtype, pre-operative CEA,
TNM staging (AJCC, 7th edition, 2010), recurrence site and overall survival.

Blood samples were collected from CRC patients during the surgery and from 7 healthy volunteers under 50 years old without $\mathrm{CRC}$ or any known genetic syndrome. All samples were stored in sterile bottles with Ethylenediaminetetraacetic acid and maintained at $-80^{\circ} \mathrm{C}$ degrees.

\section{Nucleic acid extraction and RNA quantification}

Serum or plasma microRNAs were extracted using the miRNeasy Mini $\mathrm{Kit}^{\circledR}$ (Qiagen, Hilden, Germany) ${ }^{13}$. Plasma samples were lysed with TRIzol ${ }^{\circledR}$. After the addition of chloroform and centrifugation, the aqueous phase was extracted. Ethanol was added to provide adequate binding conditions for all RNA molecules and nucleotides. The samples were then transferred to the RNeasy MinElute Spin ${ }^{\circledR}$ column. The material obtained was frozen at $-70^{\circ} \mathrm{C}$. 
For complementary DNA (cDNA) synthesis, reverse transcription was carried out using the High Capacity cDNA Reverse Transcription $\mathrm{Kit}^{\circledR}$ (Applied Biosystems). For each 5ng of RNA, $0.75 \mu 1$ of RT Buffer, $0.075 \mu 1$ of dNTP's and $1.5 \mu 1$ of specific primers (microRNAs or endogenous controls), $0.5 \mu 1$ of MultiScribe ${ }^{\circledR}$ enzyme and $0.094 \mu$ l of RNase out (1.9U) were added. The final volume of $7.5 \mu \mathrm{l}$ was obtained with Diethylpyrocarbonate-treated water. The samples were incubated in the thermal cycler for $30 \mathrm{~min}$ at $16^{\circ} \mathrm{C}, 30 \mathrm{~min}$ at $42^{\circ} \mathrm{C}, 5 \mathrm{~min}$ at $85^{\circ} \mathrm{C}$ and then $4^{\circ} \mathrm{C}$. Samples of $4.5 \mu \mathrm{l}$ of cDNA diluted to $10 \mu \mathrm{l}$ (1:4) were used for real-time PCR.

\section{Real-time PCR quantification of microRNA}

A real-time PCR was used to confirm the differential expression. From the obtained cDNA samples, a real-time quantitative reverse transcriptase polymerase chain reaction (RQPCR) was performed using the TaqMan Master Mix (Applied Biosystems). Quantitative analysis of the expression was carried out using the TaqMan Assay Kit (Assays-on-demand) (Applied Biosystems).

Relative quantification of microRNAs was performed using TaqMan Master Mix ${ }^{\circledR}$ reagent (Applied Biosystems, USA). The real-time PCR reactions were carried out in duplicate. Amplification was performed in a final volume of $10 \mu 1(5 \mu l$ of TaqMan Master Mix ${ }^{\circledR}, 0,5 \mu$ l of each specific probe and $4,5 \mu l$ of cDNA). CT values were obtained using the 7500 Real-Time PCR System ${ }^{\circledR}$ (Applied Biosystems, USA) and the Sequence Detection System ${ }^{\circledR}$ software. $\Delta$ CT values were calculated using Microsoft ${ }^{\circledR}$ Excel ${ }^{\circledR}$ calculation. Statistical analysis and graphics generation were carried out using the GraphPad Prism 6.0® software (GraphPad Prism Inc., San Diego, CA, USA).

Standard amplification conditions were $95^{\circ} \mathrm{C}$ for 10 minutes, followed by 40 cycles of $95^{\circ} \mathrm{C}$ for 15 seconds and $60^{\circ} \mathrm{C}$ for 1 minute (annealing and simultaneous extension). All reactions were performed in duplicate and analyzed in the 7500 Sequence Detection System ${ }^{\circledR}$ (Applied Biosystems, USA). During the PCR data were continuously collected and analyzed in ABI-7500 SDS software.

\section{Statistical analysis}

Continuous variables were presented as mean, median, minimum and maximum values. Absolute and percentage frequency were used to analyze numerical values. Mann-Whitney and Kruskal-Wallis tests were used to compare unpaired and
non-Gaussian groups. The Spearman correlation test was used to analyze overall survival and preoperative CEA values. A 5\% level of significance $(\alpha=0.05)$ was considered for rejection of the null hypothesis.

\section{Results}

The main clinical and pathological characteristics of the patients are described in Table 1.

TABLE 1 - Clinical and pathological characteristics of the patients

\begin{tabular}{|c|c|}
\hline Characteristics & Number of patients \\
\hline \multicolumn{2}{|l|}{ Gender } \\
\hline Male & $19(51.4 \%)$ \\
\hline Female & $18(48.6 \%)$ \\
\hline \multicolumn{2}{|l|}{ Age } \\
\hline$<60$ years & $14(37.8 \%)$ \\
\hline$\geq 60$ years & $23(62.2 \%)$ \\
\hline \multicolumn{2}{|l|}{ Tumor localization } \\
\hline Colon & $19(51.4 \%)$ \\
\hline Rectum & $18(48.6 \%)$ \\
\hline \multicolumn{2}{|l|}{ Preoperative CEA } \\
\hline Elevated (>5ng/dl) & $23(62.2 \%)$ \\
\hline Normal $(<5 \mathrm{ng} / \mathrm{dl})$ & $14(37.8 \%)$ \\
\hline \multicolumn{2}{|l|}{ TNM staging } \\
\hline I & $1(2.7 \%)$ \\
\hline II & $15(40.5 \%)$ \\
\hline III & $13(35.2 \%)$ \\
\hline IV & $8(21.6 \%)$ \\
\hline \multicolumn{2}{|l|}{ Recurrence } \\
\hline Yes & $14(37.8 \%)$ \\
\hline No & $23(62.2 \%)$ \\
\hline \multicolumn{2}{|l|}{ Recurrence site } \\
\hline Local & $3(21.4 \%)$ \\
\hline Systemic & $11(78.6 \%)$ \\
\hline \multicolumn{2}{|c|}{ Overall Survival (months) } \\
\hline Mean & 38.2 \\
\hline Minimum & 3 \\
\hline Maximum & 52 \\
\hline
\end{tabular}

The expression of miR-21 was lower in the colorectal cancer group $(P<0.001)$ and in colorectal cancer patients younger than 60 years old $(P=0.01)$. No difference was noted comparing subjects with or without recurrence $(P=0.06)$ and among TNM staging subgroups $(P=0.32)$. There was no correlation between miR-21 expression, CEA levels, and overall survival.

MicroRNA-34a was underexpressed in subjects with CRC $(P<0.001)$ and patients younger than 60 years $(P<0.001)$. No statistical difference was noted comparing patients with or without 
recurrence $(P=0.74)$ and between TNM staging groups $(P=0.22)$. There was no correlation between miR-34a expression, CEA levels, and overall survival.

The circulating levels of miR-126 were lower in CRC subjects $(\mathrm{P}<0.001)$ and in patients under 60 years $(\mathrm{P}<0.001)$. No difference was noted comparing subjects with or without recurrence
$(P=0.89)$ and among TNM staging subgroups $(P=0.31)$. There was no correlation between miR-126 expression, CEA levels and global survival.

The expression of each microRNA according to CEA levels, TNM staging group and recurrence are illustrated in figure 2 .
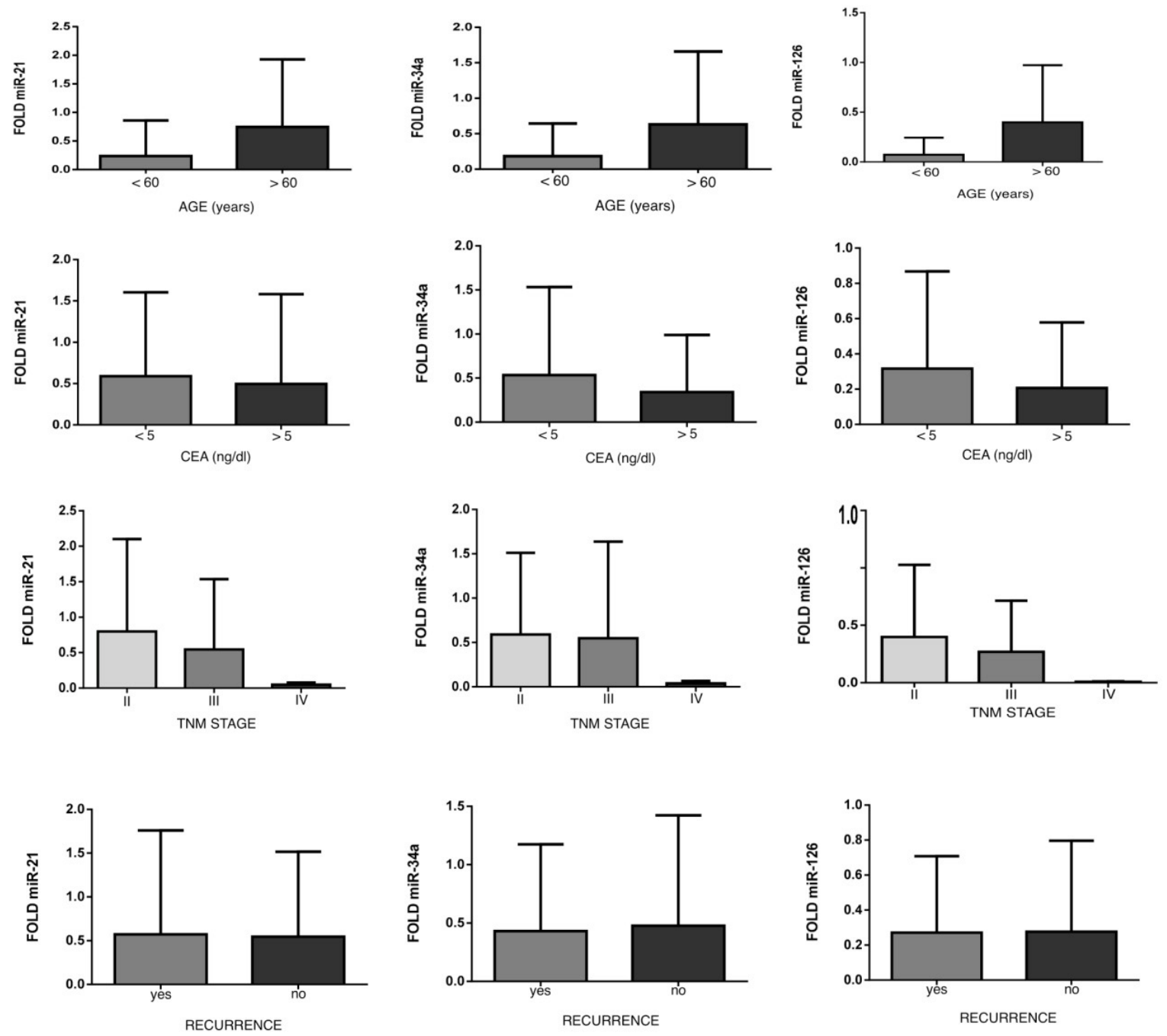

FIGURE 2 - Expression of microRNAs (mean \pm standard deviation) according to age groups, CEA levels, TNM staging and recurrence

\section{Discussion}

The full understanding of miRNAs role on carcinogenesis is a laborious task since their function may vary according to the target tissue and may be influenced by population and environmental characteristics ${ }^{14,15}$. Some tumor-specific alterations in nucleic acids promise non-invasive biomarkers that can be detected in the plasma of patients ${ }^{12,16}$.

The miR-21 inhibits the expression of tumor suppressive genes and induces cell proliferation ${ }^{17}$. An overexpression of miR21 has been found in breast, pancreas, prostate and colorectal cancerand has been linked to more advanced TNM stages, lower cellular differentiation decreased overall survival and reduced disease-free survival ${ }^{18-20}$. This correlation with a poorer prognosis could help determine patients who would benefit from a personalized treatment ${ }^{21}$. The present study found no relation between miR-21 and CRC prognosis. This finding could be explained by a wide variation in serum levels of miR-21, in patients with colon and rectal cancer ${ }^{22,23}$.

MicroRNA-34a can act as a tumor suppressor by regulating proliferation, invasion, metastasis and apoptosis ${ }^{10}$. Reduced serum levels of miR-34 were noticed in a group of CRC 
patients and human colorectal cancer 5-fluorouracil-resistant DLD-1 cells ${ }^{24,25}$. Furthermore, when valued tissue expression, $36 \%$ of colon cancer samples showed decreased expression of miR-34a compared to noncancerous colon specimen ${ }^{26}$. However, the precise correlation between miR-34 levels and prognosis is still under investigation ${ }^{27}$.

A high expression of miR-126 inhibited cell proliferation, migration, and invasion, suggesting that it may act as a tumor suppressor $^{28}$. Low expression of miR-126 have been related to poor prognosis in colon cancer patients ${ }^{29,30}$. This finding was not confirmed by the present study. Further investigation is necessary to identify specific microRNAs that can act as prognostic tools in colorectal cancer.

\section{Conclusion}

This study suggests that the expression of miR-21, miR34a and miR-126 was lower in the CRC group and CRC subjects younger than 60 years old. No associations with CEA values, TNM staging, and histological subtype were noted and, contrary to what has been evidenced, the present study found no association of those biomarkers with poor prognosis.

\section{References}

1. Gryfe R, Kim H, Hsieh ET, Aronson MD, Holowaty EJ, Bull $\mathrm{SB}$, Redston M, Gallinger S. Tumor microsatellite instability and clinical outcome in young patients with colorectal cancer. N Engl J Med. 2000;342(2):69-77. PMID:10631274.

2. Instituto Nacional de Câncer José Alencar Gomes da Silva (INCA). Estimativa 2014: incidência de câncer no Brasil. In Vigilância CdPe, editor. Rio de Janeiro: INCA; 2014:124.

3. Andre T, Quinaux E, Louvet C, Colin P, Gamelin E, Bouche O, Achille E, Piedbois P, Tubiana-Mathieu N, Boutan-Laroze A, Flesch M, Lledo G, Raoul Y, Debrix I, Buyse M, de Gramont A. Phase III study comparing a semimonthly with a monthly regimen of fluorouracil and leucovorin as adjuvant treatment for stage II and III colon cancer patients: final results of GERCOR C96.1. J Clin Oncol. 2007;25(24):3732-8. PMID:17704423.

4. Liebig C, Ayala G, Wilks J, Verstovsek G, Liu H, Agarwal N, Berger $\mathrm{DH}$, Albo D. Perineural invasion is an independent predictor of outcome in colorectal cancer. J Clin Oncol. 2009;27(31):5131-7. PMID:19738119.

5. Prandi M, Lionetto R, Bini A, Francioni G, Accarpio G, Anfossi A, Ballario E, Becchi G, Bonilauri S, Carobbi A, Cavaliere P, Garcea D, Giuliani L, Morziani E, Mosca F, Mussa A, Pasqualini M, Poddie D, Tonetti F, Zardo L, Rosso R. Prognostic evaluation of stage B colon cancer patients is improved by an adequate lymphadenectomy: results of a secondary analysis of a large scale adjuvant trial. Ann Surg. 2002;235(4):458-63. PMID:11923600.

6. Le Voyer TE, Sigurdson ER, Hanlon AL, Mayer RJ, Macdonald JS, Catalano PJ, Haller DG. Colon cancer survival is associated with increasing number of lymph nodes analyzed: a secondary survey of intergroup trial INT-0089. J Clin Oncol. 2003;21(15):2912-9. PMID:12885809.
7. Kavitha N, Vijayarathna S, Jothy SL, Oon CE, Chen Y, Kanwar JR, Sasidharan S. MicroRNAs: biogenesis, roles for carcinogenesis and as potential biomarkers for cancer diagnosis and prognosis. Asian Pac J Cancer Prev. 2014;15(18):7489-97. PMID:25292018.

8. Schepeler T, Reinert JT, Ostenfeld MS, Christensen LL, Silahtaroglu AN, Dyrskjøt L, Wiuf C, Sørensen FJ, Kruhøffer M, Laurberg S, Kauppinen S, Ørntoft TF, Andersen CL. Diagnostic and prognostic microRNAs in stage II colon cancer. Cancer Res. 2008;68(15):6416-24. PMID:18676867.

9. Faber C, Kirchner T, Hlubek F. The impact of microRNAs on colorectal cancer. Virchows Arch. 2009;454(4):359-67. PMID:19288129.

10. Esquela-Kerscher A, Slack FJ. Oncomirs - microRNAs with a role in cancer. Nat Rev Cancer. 2006;6(4):259-69. PMID:16557279.

11. Hrašovec S, Glavač D. MicroRNAs as Novel Biomarkers in Colorectal Cancer. Front Genet. 2012;3:180. doi: 10.3389/ fgene.2012.00180.

12. Mitchell PS, Parkin RK, Kroh EM, Fritz BR, Wyman SK, PogosovaAgadjanyan EL, Peterson A, Noteboom J, O'Briant KC, Allen A, Lin DW, Urban N, Drescher CW, Knudsen BS, Stirewalt DL, Gentleman R, Vessella RL, Nelson PS, Martin DB, Tewari M. Circulating microRNAs as stable blood-based markers for cancer detection. Proc Natl Acad Sci U S A. 2008;105(30):10513-8. PMID:18663219.

13. Kroh EM, Parkin RK, Mitchell PS, Tewari M. Analysis of circulating microRNA biomarkers in plasma and serum using quantitative reverse transcription-PCR (qRT-PCR). Methods. 2010;50(4):298301. PMID:20146939.

14. Chiang Y, Song Y, Wang Z, Chen Y, Yue Z, Xu H, Xing C, Liu Z. Aberrant expression of miR-203 and its clinical significance in gastric and colorectal cancers. J Gastrointest Surg. 2011;15(1):6370. PMID:21063914.

15. Brennecke J, Stark A, Russell RB, Cohen SM. Principles of microRNA-target recognition. PLoS Biol. 2005;3(3):e85. PMID:15723116.

16. Frattini M, Gallino G, Signoroni S, Balestra D, Lusa L, Battaglia L, Sozzi G, Bertario L, Leo E, Pilotti S, Pierotti MA. Quantitative and qualitative characterization of plasma DNA identifies primary and recurrent colorectal cancer. Cancer Lett. 2008;263(2):170-81. PMID:18395974.

17. Asangani IA, Rasheed SA, Nikolova DA, Leupold JH, Colburn NH, Post S, Allgayer H. MicroRNA-21 (miR-21) post-transcriptionally downregulates tumor suppressor Pdcd4 and stimulates invasion, intravasation and metastasis in colorectal cancer. Oncogene. 2008;27(15):2128-36. PMID:17968323.

18. Yan LX, Huang XF, Shao Q, Huang MY, Deng L, Wu QL, Zeng YX, Shao JY. MicroRNA miR-21 overexpression in human breast cancer is associated with advanced clinical stage, lymph node metastasis and patient poor prognosis. RNA. 2008;14(11):2348-60. PMID:18812439.

19. Shibuya $H$, Iinuma $H$, Shimada $R$, Horiuchi $A$, Watanabe $T$. Clinicopathological and prognostic value of microRNA-21 and microRNA-155 in colorectal cancer. Oncology. 2010;79(3-4):31320. PMID:21412018.

20. Liu K, Li G, Fan C, Zhou X, Wu B, Li J. Increased expression of microRNA-21and its association with chemotherapeutic response in human colorectal cancer. J Int Med Res. 2011;39(6):2288-95. PMID:22289545.

21. Zhang JX, Song W, Chen ZH, Wei JH, Liao YJ, Lei J, Hu M, Chen GZ, Liao B, Lu J, Zhao HW, Chen W, He YL,Wang HY, Xie D, Luo JH. Prognostic and predictive value of a microRNA signature in stage II colon cancer: a microRNA expression analysis. Lancet Oncol. 2013;14(13):1295-306. PMID:24239208.

22. Schee K, Boye K, Abrahamsen TW, Fodstad O, Flatmark K. Clinical relevance of microRNA miR-21, miR-31, miR-92a, miR-101, miR- 
106a and miR-145 in colorectal cancer. BMC Cancer. 2012;12:505. PMID:23121918.

23. Luo X, Stock C, Burwinkel B, Brenner H. Identification and evaluation of plasma microRNAs for early detection of colorectal cancer. PloS One. 2013;8(5):e62880. PMID:23690963.

24. Nugent M, Miller N, Kerin MJ. Circulating miR-34a levels are reduced in colorectal cancer. J Surg Oncol. 2012;106(8):947-52. PMID:22648208.

25. Akao Y, Noguchi S, Iio A, Kojima K, Takagi T, Naoe T. Dysregulation of microRNA-34a expression causes drug-resistance to 5-FU in human colon cancer DLD-1 cells. Cancer Lett. 2011;300(2):197204. PMID:21067862.

26. Tazawa H, Tsuchiya N, Izumiya M, Nakagama H. Tumorsuppressive miR-34a induces senescence-like growth arrest through modulation of the E2F pathway in human colon cancer cells. Proc Natl Acad Sci U S A. 2007;104(39):15472-7. PMID:17875987.

27. Misso G, Di Martino MT, De Rosa G, Farooqi AA, Lombardi A, Campani V, Zarone MR, Gullà A,Tagliaferri $\mathrm{P}$, Tassone $\mathrm{P}$, Caraglia M. Mir-34: a new weapon against cancer? Mol Ther Nucleic Acids. 2014;3:e194. PMID:25247240.

28. Liu Y, Zhou Y, Feng X, An P, Quan X, Wang H, Ye S, Yu C, He Y, Luo H. MicroRNA-126 functions as a tumor suppressor in colorectal cancer cells by targeting CXCR4 via the AKT and ERK1/2 signaling pathways. Int J Oncol. 2014;44(1):203-10. PMID:24189753.

29. Liu Y, Zhou Y, Feng X, Yang P, Yang J, An P, Wang H, Ye S, Yu C, He Y, Luo H. Low expression of microRNA-126 is associated with poor prognosis in colorectal cancer. Genes Chromosomes Cancer. 2014;53(4):358-65. PMID:24532280.

30. Sideris M, Papagrigoriadis S. Molecular biomarkers and classification models in the evaluation of the prognosis of colorectal cancer. Anticancer Res. 2014;34(5):2061-8. PMID:24778007.

\section{Correspondence:}

Marley Ribeiro Feitosa

Av. Bandeirantes, 3900 - Campus Universitário - Monte Alegre - $9^{\circ}$ andar 14048-900 - Ribeirão Preto, São Paulo, Brasil

Tel.: (55 16) 3602-2509

marleyfeitosa@yahoo.com.br

Conflict of interest: none

Financial source: none

${ }^{1}$ Research performed at the Division of Coloproctology, Department of Surgery and Anatomy, Ribeirão Preto Medical School, University of São Paulo. 